\title{
SURGICAL MANAGEMENT OF SYMPTOMATIC LOW BACK PAIN AND MONORADICULAR LEG PAIN IN ADOLESCENT AND YOUNG ADULT PATIENTS
}

\author{
Kalevski Svetoslav, ${ }^{1}$ Haritonov Dimiter, ${ }^{1}$ Peev Nikolay, ${ }^{1}$ Kalevska Evgenia ${ }^{2}$ \\ ${ }^{1}$ Department of Neurosurgery, Medical University - Varna "St. Anna" Multiprofile Hospital — Varna, Bulgaria \\ ${ }^{2}$ Department of Neurology, Medical University - Varna, "St. Marina" Multiprofile Hospital — Varna, Bulgaria \\ Primljen/Received 04. 05. 2014. god. \\ Prihvaćen/Accepted 15. 06. 2014. god.
}

Abstract: Objectives: The purpose of the present retrospective study is to draw attention to symptomatic low back pain in adolescent patients, in order to encourage earlier diagnosis and surgical treatment. The study assessed the radiological, clinical features and surgical outcomes of 13of this kind of patient.

Materials and Methods: Out of a series of 983 consecutive cases (1999-2011) of lumbar disc excisions from our neurosurgical institution, $13-1,32 \%$ of the patients were between the ages of 15 and 20 mean 17,84 . Fifteen operations, including two reoperations, were performed on this patient group, by a conventional microsurgical procedure. The indications for surgery were failure of conservative treatment, intractable pain and/or progressive neurological impairment.

Results: Low back pain and monoradicular sciatica were the main complaints in $77 \%$, but findings of neurological deficits were rare -1 case. The surgical findings revealed a protruding disc in eleven cases, one lateral recess stenosis and one lumbar synovial cyst. Initially, all patients were treated conservatively by their physicians more than 3 months without success. On the day of discharge, Kirkaldy-Willis criteria results were excellent or good in $92 \%$ of patients. The follow-up period ranged from 6 months to 2 years with an average of 1 year and 2 months. The results were excellent in 10 patients and good in 3 patients.

Discussion: We demonstrate that the cause of low back pain and monoradicular leg pain in adolescent patients may not only be a cause of herniated lumbar disc or lateral recess narrowing. Very rarely these symptoms may be caused by lumbar synovial cysts.

Conclusion: Surgical treatment of adolescent patients is able to relieve the clinical symptoms quickly.
Clinical symptoms such as low back pain and leg pain and the neurologic deficit disappear within 3 months after surgery.

Key words: adolescent, disk, herniation, surgery, treatment.

\section{INTRODUCTION}

Degenerative changes in the intervertebral disc begin at the late teens, after the completion of the physical growth and development, during which posterior herniation of the nucleus pulposus can cause sciatica because of nerve root compression (1). Symptomatic low back pain and monoradicular leg pain are rare in patients under age of 20 years $(2,3,4)$. There are a number of differential diagnoses to be considered in patients with the mentioned complaints (5). Most often they are due to lumbar disc herniation (LDH). Another cause of radiculopathy in adolescents could be spinal tumors $(5,6)$. They are also in the domain of the neurologists and neurosurgeons, because many of them may present with neurologic deficits (7). Epiphyseal ring fracture, disc space infection, congenital malformations and spinal synovial cysts also could be considered $(5,6,8,9,10)$. Lumbosacral intervertebral disc changes that cause sciatica and other neurological manifestations in the lower extremities are generally thought to be encountered mostly among the adults in the third decade of their life or later (11). Lumbar disc herniation is rare in children and adolescents (12). The clinical presentation and aetiology of (LDH) may differ from that in adults $(5,13)$. While the true incidence is not known, studies have shown that of all patients operated for disc herniation, less than 3\%are under 20 years of age $(14,15)$. Like the incidence, the aetiology 
and clinical presentation of (LDH) in the younger age groups also differ from that of the adults $(12,16,17)$. The characteristic features of adolescent herniated lumbar discs (HLDs) are as follows: 1) a soft protruded disc, 2) no severe spine degeneration, 3)the typical disco genic pain is usually due to a single nerve root compression, 4) it is frequently trauma related, 5) the symptom duration is relatively short-termed, 6) it is sometimes combined with a degenerative process and a bony spur such as posterior Schmorl's node $(18,19)$.

The purpose of the present investigation is to draw attention to this condition in young patients, in order to encourage earlier diagnosis and treatment. This study was designed to assess the radiological, clinical features and surgical outcomes of 13 adolescent patients with symptomatic low back pain and monoradicular leg pain. Leg pain is the primary presenting symptom in this group of patients and is often not recognized as the radicular pain of a herniated disk by the primary care physician (20). Although extremely rare in adolescents, radiculopathy and back pain can be due to lumbar synovial cyst (LSC) (10).

\section{MATERIALS AND METHODS}

Retrospectively were investigated 983 consecutive cases (1999-2011)of lumbar disc excisions done in our neurosurgical institution. The investigation selected $13(1.32 \%)$ of the patientsbetween 15 and 20 years old (mean 17.84). There were 7 male and 6 female patients. Nine patients $(69.2 \%)$ had history of sport injuri-

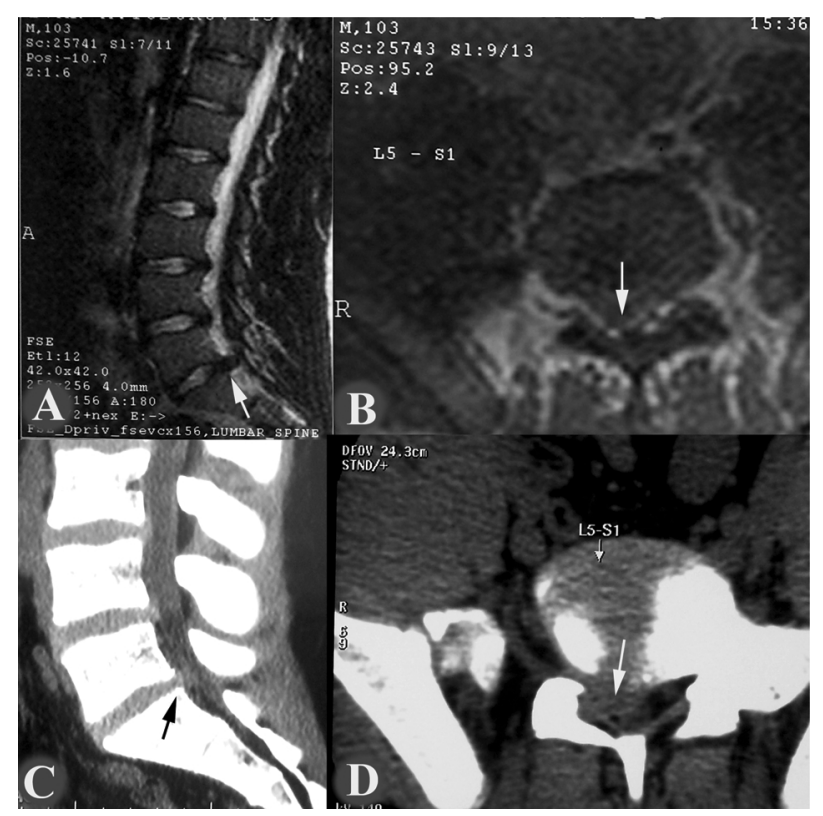

Figure 1. T2-weighted Magnetic resonance imaging $(A, B)$ and $C T$ scan $(C, D)$ of $15 M$ showing right-sided disc herniation at L5/S1 level, impinging the right $S 1$ nerve root es, trauma, or lifting heavy objects before the onset of the symptoms. All patients had been treated with at least one of the following: bed rest, physiotherapy, medication, and chiropractic treatments. The indications for surgery include:1) intractable pain and failure of the conservative treatment for more than 3 months, 2) radiographic diagnosis of intervertebral disc herniation or other nerve root compression based on computed tomography (CT) or magnetic resonance imaging (MRI), and 3 ) progressive neurological impairment. In all of the reported cases, the diagnosis was achieved preoperatively by lumbar spine MRI (Figure 1). A single-level unilateral for aminotomy or partial laminectomy was performed to remove the herniated part of disc and decompress the affected nerve root. Subjective complaints and neurological findings were recorded one day before surgery and on the day of discharge (3-12 days following surgery, mean 8 days). The follow-up period ranged from 6 months to 2 years with an average of 1year and 2 months, was monitored on an out-patient basis and by questionnaire or telephone interview. The results were analysed using the Kirkaldy-Willis criteria (21) (Table 1) and VAS.

Table 1. The criteria of Kirkaldy-Willis, et al. for the functional outcome

\begin{tabular}{|c|l|}
\hline Grade & \multicolumn{1}{|c|}{ Description } \\
\hline Excellent & $\begin{array}{l}\text { The patient has returned to his normal } \\
\text { work and other activities with little or no } \\
\text { complaint }\end{array}$ \\
\hline Good & $\begin{array}{l}\text { The patient has returned to his normal } \\
\text { work but may have some restriction in } \\
\text { other activities and may onoccasion after } \\
\text { heavy work have recurrent back pain re- } \\
\text { quiring a rest for a few days }\end{array}$ \\
\hline Fair & $\begin{array}{l}\text { The patient has to reduce his working ca- } \\
\text { pacity, taking a lighter job or work } \\
\text { part-time, and may occasionally have re- } \\
\text { currence of pain requiring absence from } \\
\text { work for one to two weeks, once or twice } \\
\text { a year }\end{array}$ \\
\hline Poor & \begin{tabular}{l} 
The patient does not return to work \\
\hline
\end{tabular} \\
\hline
\end{tabular}

\section{RESULTS}

Patient characteristics: The ratio of male to female patients was 1.16:1. The incidence of LDHs treated surgically in adolescent patients was $1.32 \%$ in the series of 983 operations for LDH performed during the study period. No one of the patients was found to have a congenital malformation or familial predisposition.

Clinical symptoms: Low back pain and monoradicular sciatica were the main complaints in $77 \%$ of the 

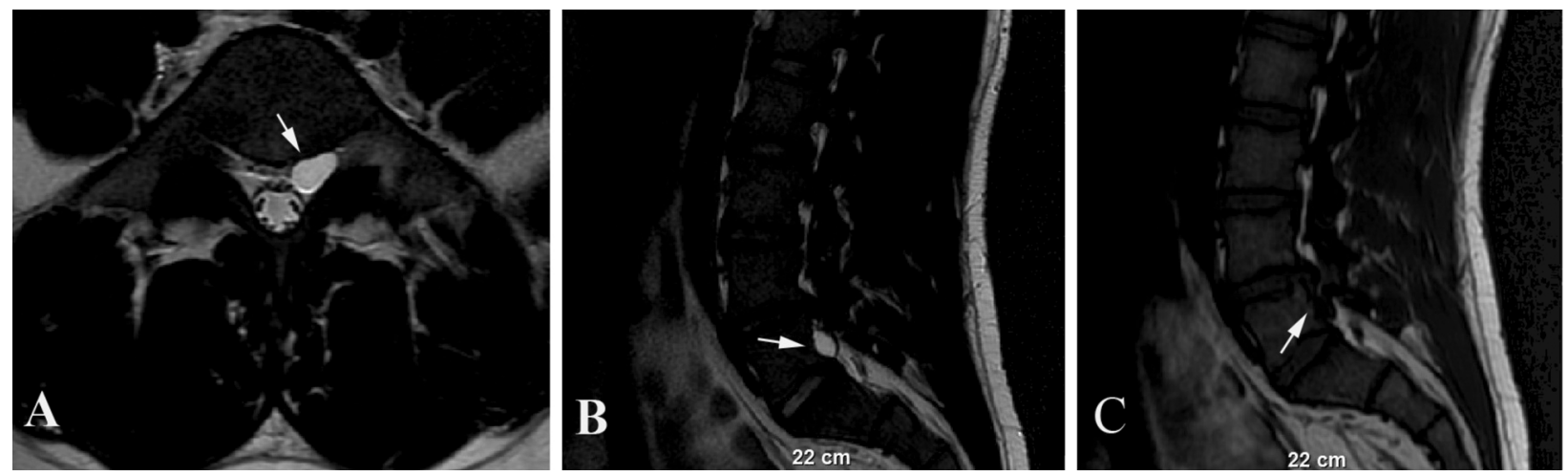

Figure 2. Magnetic resonance imaging showing a 1,5-cm intraspinal synovial cyst originating from the left L4-L5 facet joint with low intensity on T1-weighted images (C) and hyperintenseon T2-weighted images (B), lying in the spinal canal at the L5 vertebral body level and extending into the neural foramen (A)

patients. Two patients only had radicular leg pain. Only 1 patient among the 13 patients experienced low back pain without leg pain. Forward flexion of the spine had been limited in all patients. Paresthesia had been present in 7 patients (54\%) and in 6 of them the S1 dermatome had been found involved and 1 hadL5dermatome involved. Only one patient was found to have Neurological deficit - 1case with peroneal nerve palsy. At the time of surgery, the straight leg raising test was positive in all 13 patients. All of the patients had symptoms duration period for more than 3 months, and 5 patients had symptoms duration for 1 year or more. The reason for the long period of complaints duration is late establishment of the diagnosis by the treating physicians and initial refusal of the proposed surgical treatment.

Radiological findings: The level of disc herniation was found to be L4-L5 in two patients and L5-S1 in nine patients. One patient had congenital stenosis at level L4-L5 and another patient had lumbar synovial cyst (LSC) at the same level (Figure 1). Five patients had CT scans followed by lumbar spine MRI for establishing the proper diagnosis. Epiphysealring fracture was found in 4 of the 5 patients who underwent $\mathrm{CT}$ study $(80 \%)$ (Figure 2). The CT scan of the patient with LSC initially detected nothing abnormal, thus the patient had been treated conservatively for a year. The diagnosis in the rest 8 patients was established with MRI only. Disc herniation was found to be located laterally in 9 patients and 2 patients had central disc herniation. According to the preoperative radiological findings we classified the disc herniation as 1 bulging disc, 7 protruding discs, 2 extruding discs and 1 sequestered disc. In our series segmental instability was not found.

Surgical results: A single-level unilateral micro-disc excision and for aminotomy was performed to remove the herniated disc and decompress the affected nerve root in 7 patients. The other six patients had unilateral hemilaminectomy for a central herniated disc, fractured apophysis or LSC. Two patients had subsequ- ent reoperations. They had good results initially. The first patient had been re-operated 5 months after the initial discectomy. Recurrent disc herniation at the same level and side with incapacitating pain led to second operation. Excellent result had been achieved after the second operation. The second patient had deep wound infection - epiduritis and thus re-operated6months after the first discectomy. The infection had been cured and the final result had been graded as good. For the re-operated patients, instrumented fusion was not considered as necessary option, due to the young age.

On the day of discharge, Kirkaldy-Willis criteria results were excellent or good in $92 \%$ of patients. The follow-up period ranged from 6months to 2 years with an average of 1year and 2 months. The results were excellent in 10 patients and good in 3patients. The mean postoperative VAS leg pain score at final follow-up had been 2 points (range, 0-5), from 6.8 mean before surgery (range, 4-10). A decrease of more than 2 points on the VAS had been observed in $77 \%$ (10) of the patients. The mean VAS back pain score at final follow-up is 2.2 points (range, $0-5$ ), from 4.8 mean before surgery(range, $0-9$ ).

\section{DISCUSSION}

Symptomatic low back pain and monoradicular leg pain are rarely seen in adolescents $(3,4,12,19)$. As a most common cause for such complaints the multitude of the authors define $\operatorname{LDH}(4,22)$. Rarely spinal tumors, apophyseal ring fractures, disc infections, vertebral anomalies, congenital stenosis or LSC could also be a causative $(5,6,8,9,10,18,23)$. The establishment of a proper diagnosis could be extremely difficult because of the paucity of neurologic signs and symptoms and the subsequent high grade suspicions for hysteria (18). All this often causes late diagnosis establishment, delay of the operative treatment and unjustified prolonged conservative treatment. The characteristics of adolescent LDH are soft protruded disc, no severe spine degeneration, typical disco genic pain that is usually 
due to a single nerve root compression, relatively short symptom duration, it is frequently related to back trauma, and LDH is sometimes combined with a degenerative process and bony spur formation such as posterior Schmorl's node (19). Traumatic events appear to be crucial factor in the occurrence of LDH in adolescent patients in contrast to adults $(3,9,12,15)$. Trauma isfrequently reported as the primary causative factor with variable incidence. In this study, 9 (69\%) cases developed symptoms after trauma (sports, heavy lifting, and falling, extreme flexion-extension). Three of them additionally had been found to have apophyseal ring fractures. The remaining four patients have not mentioned any specific traumatic event.

The rate of LDH among adolescents if compare to adults varies in wide range $0,5-6,8 \%(6,18,19)$. Sung-Uk, et al. (19) report for $4 \%$ operated adolescents with LDH, out of 4530 operated LDH. Giroux, et al. (17) have found $1 \% \mathrm{LDH}$ in the age $13-18$ years and $3.7 \%$ in the age $13-21$ years. Russwurm, et al. (15) have found that $3.6 \%$ out of 37 patients are adolescent operated for LDH. All the authors report for rapid increase of the $\mathrm{LDH}$ rate over the age of 18 years $(6,17)$. With our investigation in concordance with the other authors we have found rate $1.32 \%$ of the adolescent LDH.

The clinical presentation of adolescent LDH is generally similarto those observed in adults (12). According to Sung-Uk, et al., almost all adolescent LDH patients $161 / 185$ (87\%) had low back and leg pain, only $8.6 \%$ of the patients complained of low back pain alone. In our study, 12 adolescent LDH patients complained with leg pain, 10 (77\%) patients complained with leg pain together with low back pain, and just $1(8 \%)$ among the 13 patients complained with low back pain only. One distinctive feature is that up to $90 \%$ of patients had had positive straight leg raising test, which could be anatomically explained with the finding that children and adolescents tend to have greater nerve root tension than adults (18). In our study at the time prior to operation, the straight leg raising test had been positive in all 13 patients, but findings of neurological deficits were found to be very rare - 1 case.

Conservative treatment is always the first choice of treatment. Some authors report for a good outcome using conservative measures, including bed rest, analgesics, corsets, heat and other physical therapies $(5,12)$.

However, not all the reports are concordant with the conservative treatment success rate (15). In the series of Lih-Huei, et al. authors report for 28 adolescents suffered from pain and postural deformity for an average of 9 months. The authors believe hat the delay of definite diagnosis and surgery might have been the result of insidious onset of back pain in adolescents. Another reason according the authors is that doctors are reluctant to send adolescents for surgery. In our series all the patients had symptoms duration for a period of more than 3 months, and 5 patients had symptoms duration for a year or more and during this time they have been unsuccessfully treated conservatively by their doctors. Similar results were reported in studies of Kurt, et al. (4), Frino, et al. (20), Youn-Soo, et al. (9), and Russwurm, et al. (15).

Nevertheless, conservative treatment is still generally recommended as the first-line treatment for $\mathrm{LDH}$ in children and adolescents without neurological deficits.

We believe that the adolescent patients with low back pain and radicular leg pain should always be examined with CT or MRI with the onset of their first complaints. Our patient with LSC initially was not diagnosed by $\mathrm{CT}$ and was treated conservatively for more than a year. The month prior the hospitalization the intensity of the low back pain had increased, spreading to his left leg. MRI revealed a $1.5-\mathrm{cm}$ intraspinal synovial cyst originating from the left L4-L5 facet joint with low intensity on T1-weighted images and hyperintense on T2-weighted images, lying in the spinal canal at the L5 vertebral body level and extending into the neural foramen (Figure 2).

Surgical results:Microsurgical discectomy remains the most popular surgical procedure for $\mathrm{LDH}$ among children and adolescents, as well as for adults. It is generally agreed in the literature that the posterior discectomy with partial laminotomy is indicated for posterolateral disc herniation, whereas semilaminotomy or laminectomy is required in cases of central disc herniation (6). The results after surgical discectomy were generally excellent. Lih-Huei, et al. (14) reviewed 28 adolescent patients and demonstrated good andexcellent results in $93 \%$ of patients. In the series of Sung-Uk, et al. (19) the success rate of microsurgical discectomy is reported to be $97 \%$. On the day of discharge $94 \%$ of patients of Kurt, et al. (4) had reported excellent or good results. Dang end Liu (2010) in their review summarized the short-term outcome of discectomy reported in 22 published articles, the numberof cases involved had been 798. Discectomy had been associated with good short-term outcome, with the success rate ranging from 79 to $100 \%$ (weighted mean $94.9 \%$ ). However, more series with lower success rates were reported at mid-term follow-up. Continuous decrease in success rate is seen among the long-term follow-up series. Our opinion is that the microsurgical discectomy procedure relieves the clinical symptoms quickly. Clinical symptoms such as low back pain and leg pain and the neurologic disturbances disappeared within 3 months after surgery. We achieved satisfactory results for microsurgical discectomy, and the success rates were $92 \%$, after more than 1 year follow-up.

In some cases, microsurgical discectomy is followed with postoperative back pain, operation related 
risks, and foraminal restenosis due to the postoperative disc space narrowing, resulting in back pain (19).

In our series, one patient had definite recurrence of disc herniation and another patient demonstrated recurrent back pain with deep wound infection. A recurrence of the HNP was seen in $20 \%$ of the patients of Sung-Uk et al. (19). All recurrences were at the same level of the initial herniation. In the series of Durham et al. (24) among 29 operated adolescents with follow-up period ranged from 4 months to 30.5 years, the rate of reoperations had been $24 \%$ over the course of follow-up period. However, similarly to other authors, we have found that the results of surgery and the clinical outcome were not affected respectively.

\section{CONCLUSIONS}

Adolescent disc herniation is uncommon and is often caused by trauma. We propose early CT or MRI study for adolescents who have back or leg pain persi- sting for 2 to 4 weeks to aid the diagnosis of disc herniation as well as to detect apophyseal lesions, congenital stenosis or LSC that may lead to failure of conservative treatment. The surgical decision must relay on the clinical symptoms and the radiological findings. Surgical treatment of the adolescent patients relieves the clinical symptoms quickly. Clinical symptoms such as low back pain and leg pain and the neurologic disturbances disappeared within 3 months after surgery. Since the results are often excellent in this age group, the early surgical treatment is recommended.
Abbreviations
LDH - lumbar disc herniation
HLDs - herniatedlumbar discs
LSC - lumbar synovial cyst
CT - computedtomography
MRI - magnetic resonance imaging

\title{
Sažetak
}

\section{HIRURŠKO LEČENJE SIMPTOMATSKOG BOLA U DONJEM DELU LEĐA I MONORADIKULARNOG BOLA U NOZI KOD ADOLESCENATA I MLADIH}

\author{
Kalevski Svetoslav, ${ }^{1}$ Haritonov Dimiter, ${ }^{1}$ Peev Nikolay, ${ }^{1}$ Kalevska Evgenia ${ }^{2}$ \\ ${ }^{1}$ Department of Neurosurgery, Medical University — Varna "St. Anna” Multiprofile Hospital — Varna, Bulgaria \\ ${ }^{2}$ Department of Neurology, Medical University — Varna, "St. Marina" Multiprofile Hospital — Varna, Bulgaria
}

Ciljevi: Svrha ove retrospektivne studije je da skrene pažnju na simptomatski lumbalni bol kod adolescentnih pacijenata, u cilju podsticanja ranije dijagnoze i hirurškog lečenja. Studija je ocenila radiološke, kliničke i hirurške ishode kod 13 ovakvih pacijenata.

Materijali i metode: U nizu 983 uzastopnih slučajeva (1999-2011) sa isečkom lumbalnog diska, na našoj neuro-hirurškoj klinici, od 13 pacijenata - 1,32 \% su bili između 15 i 20 godina starosti. Petnaest operacija, uključujući dve reoperacije su izvedene u ovoj grupi pacijenata, konvencijalnom mikrohirurškom procedurom. Indikacije za operaciju su bili neuspesi konzervativnog lečenja, nekontrolisan bol i/ili progresivna neurološka oštećenja.

Rezultati: Bol u donjem delu leđa i išijas su bili glavne tegobe kod 77\% pacijenata, ali neurološki deficiti su bili retki — samo jedan slučaj. Hirurški nalazi su otkrili ispupčen disk kod 11 slučajeva, jednu bočnu stenozu i jednu lumbalnu sinovijalnu cistu. U početku svi pacijenti su lečeni konzervativno od strane svojih lekara, više od 3 meseca bez uspeha. Na dan otpusta po Kirkaldi-Vilis kriterijumima rezultati su bili odlični ili dobri u 92\% pacijenata. Pacijenti su praćeni u proseku od 6 meseci do 2 godine, sa prosekom od 1 godine i 2 meseca. Rezultati su označeni kao odlični kod 10, a dobro kod 3 pacijenta.

Diskusija: Demonstrirali smo da uzrok u donjem delu leđa i monoradikularni bol u nozi kod adolescenata ne mora biti uzrokovan hernijom lumbalnog diska ili usled lateralnog suženja. Veoma retko ovi simptomi mogu biti izazvani i lumbalnom sinovijalnom cistom.

Zaključak: Hirurško lečenje adolescenata može ukloniti kliničke simptome kod pacijenata jako brzo. Klinički simptomi kao što su bol u donjem delu leđa ili bol u nozi, kao i neurološki deficit nestaju u roku od 3 meseca nakon operacije.

Ključne reči: adolescent, disk, hernija, operacija, lečenje. 


\section{REFERENCES}

1. Kim MS, Park K, Hwang C, et al. Recurrence rate of lumbar disc herniation after open discectomy in active young men. Spine. 2009; 34: 24-9.

2. Mattila VM, Saarni L, Parkkari J, et al. Early risk factors for lumbar discectomy : an 11-year foollow-up of 57,408 adolescents. Eur Spine. 2008; 17: 1317-23.

3. Pietila TA, Stendel R, Kombos T, et al. Lumbar disc herniation in patients up to 25 years of age. Neurol Med Chir. $2001 ; 41: 340-4$.

4. Kurth AA, Rau S, Wang C, et al. Treatment of lumbar disc herniation in the second decade of life. Eur Spine J. 1996; 5: $220-4$.

5. Kazemi M. Adolescent lumbar disc herniation in a Tae Know Do martial artist: a case report. J Can ChiroprAssoc. 1999; 43(4): 236-42.

6. Dang L, Liu Z. A review of current treatment for lumbar disc herniation in children and adolescents. Eur Spine J. 2010; 19: 205-14.

7. Parikh SN, Crawford AH. Orthopaedic Implications in the Management of Pediatric Vertebral and Spinal Cord Tumors:A Retrospective Review. Spine. 2003; 28(20): 1390-2396.

8. Chang C, Lee Z, Chen W, Tan C, et al. Clinical significance of ring apophysis fracture in adolescent lumbar disc herniation. Spine. 2008; 33: 1750-4.

9. Kim Y, Park I, Rhyu K, et al. Surgical excision of the lumbar disc herniation in elementary school age. Asian Spine Journal. 2009; 3(1): 10-15.

10. Gelabert-González M, Prieto-González A, et al. Lumbar synovial cyst in an adolescent: case report. Child's Nervous System. 2009; 25(6): 719-21.

11. Mandel A. Lumbosacral intervertebral disc disease in children. California Medicine. 1960; 93(5): 307-8.

12. King L, Mior SA, Devonshire-Zielonka K. Adolescent lumbar disc herniation: a case report. J Can ChiroprAssoc. 1996; 40(1): $15-18$
13. Zhu Q, Gu R, Yang X, et al. Adolescent lumbar disc herniation and hamstring tightness. Spine. 2006; 31(16): $1810-14$.

14. Lih-Huei Chen, Chia-Hsieh Chang, et al. Intervertebral disc herniations in adolescents. Chang Gung Med J. 2004; 27(1): 22-8.

15. Russwurm H, Bjerkreim I, Ronglan E. Lumbar intervertebral disc herniation in the young. Acta Orthop Scand. 1978; 49: 158-63.

16. Silvers HR, Lewis PJ, Clabeaux DE, et al. Lumbar disc excisions in patients under the age of 21 years. Spine. 1994; 19(21): 2387-91.

17. Giroux, JC, Leclercq,TA. Lumbar disc excision in the seconddecade. Spine. 1982; 7(2): 168-70.

18. Epstein J, Epstein NE, Marc J, et al. Lumbar intervertebral disk herniation in teenage children: Recognition and management of associated anomalies. Spine. 1984; 9(4): 427-32.

19. Sung-Uk K, Young-Soo K, Young-Eun C, et al. Surgical treatment for lumbar disc disease in adolescent patients; Chemonucleolysis / Microsurgical Discectomy / PLIF with Cages. YonseiMedical Journal. 2005; 46(1): 125-32.

20. Frino J, McCarthy RE, Sparks CY, et al. Trends in adolescent lumbar disk herniation. J PediatrOrthop. 2006; 26: 579-81.

21. Kirkaldy-Willis WH, Paine KW, Cauchoix J, McIvorG:Lumbar spinal stenosis. Clin Orthop Relat Res. 1974; (99): 30-50.

22. Dewing CB, Provencher MT, Riffenburg RH, et al. The outcome of lumbar microdiscectomy in a young, active population. Spine. 2008; 33(1): 33-8.

23. Salminen JJ, Erkintalo MO, Pentti J, et al. Recurrent low back pain and early disc degeneration in the young. Spine. 1999;24 (13): 1316-20.

24. Durham SR, Sun PP, Sutton LN. Surgically treated lumbar disc disease in the pediatric population: an outcome study. J Neurosurgery:Spine. 2000; 92(1): 1-6.

\section{Correspondence to / Autor za korespondenciju}

Assoc. Prof. SvetoslavKalevski, MD, PhD., Neurosurgeon

Dep. Neurosurgery

Medical University of Varna

55 "Marin Drinov" Str.

BG-9002 Varna, Bulgaria

Mobile: +359 888212387

E-mail: dr_kalevski@abv.bg

Fax: +35952355553 